\title{
Pengembangan Material Komposit Serat Nanas untuk Desain Produk Furnitur
}

\author{
Rida` Millati dan Andhika Estiyono \\ Departemen Desain Produk, Fakultas Arsitektur Desain dan Perencanaan, \\ Institut Teknologi Sepuluh Nopember (ITS) \\ e-mail: rida12@mhs.prodes.its.ac.id
}

\begin{abstract}
Abstrak - Indonesia adalah produsen nanas terbesar keenam di dunia. Berdasarkan data dari portal perdagangan India, tercatat bahwa area perkebunan nanas di Indonesia adalah 20ha dengan produksi nanas sebesar 1390,38 ton dalam setahun (2010-2011). Tanaman nanas harus ditanam kembali setiap 3 bulan, sehingga jumlah limbah daun nanas melimpah. Limbah nanas ini diolah menjadi serat melalui proses ekstraksi. Serat-serat ini dimanfaatkan sebagai bahan utama produk fashion, apparel, dan komponen otomotif di Indonesia. Namun bisnis ini semakin menurun dalam 3 tahun terakhir. Harga jual produk kerajinan serat daun nanas tidak bisa maksimal karena kurangnya eksplorasi nilai estetika dan kekuatan. Berdasarkan fakta tersebut, penulis memulai penelitian dengan wawancara mendalam dan survei kepada petani nanas dan pengrajin, diikuti dengan studi perlakuan material kemudian menciptakan moodboard dan menginvestegasi calon konsumen melalui analisis aktivitas, persona, segmentasi pasar dan market positioning. Penelitian ini tidak hanya merupakan wacana pelestarian bisnis lokal di Indonesia, tetapi juga memberikan beberapa solusi alternatif untuk mengoptimalkan kekuatan, nilai estetika dan ekonomi dari daun nanas. Ini menerapkan konsep rustic dalam produk furnitur dengan mengekspos karakteristik material. Kami juga merancang alat khusus untuk mengoptimalkan kualitas proses memilin dan menganyam.
\end{abstract}

Kata Kunci-limbah serat daun nanas, desain produk, rustic, furnitur.

\section{PENDAHULUAN}

$\mathrm{D}$ ALAM dunia industri terdapat 2 jenis serat yaitu serat sintetis yang dibuat oleh manusia dan serat alam yang dihasilkan oleh alam. Menurut Kirby [1] berdasarkan asal serat tersebut diambil, serat tumbuhan dibagi menjadi serat biji, serat bast dan serat daun. Serat nanas termasuk dalam serat yang berasal dari daun.

Proses ekstraksi serat nanas dapat dilakukan dengan 2 cara, manual dan memakai mesin dekortikasi. Proses manual dapat memakai 2 jenis alat diantaranya adalah pisau dan direndam ke dalam air. Berdasarkan hasil survey petani serat nanas, ekstraksi manual menggunakan pisau lebih sederhana dan cepat dibandingkan pembusukan dengan air.

Serat Nanas dimanfaatkan sebagai bahan dasar berbagai jenis produk diantaranya adalah; pinatex yang merupakan kulit sintetis untuk produk apparel, kain untuk produk fashion, craft, furnitur leather for apparel, fabric for clothes, kerajinan, dan komposit sebagai material pembentuk komponen mesin otomotif. Sayangnya produk-produk tersebut kurang mengoptimalisasi nilai yang terkandung dalam serat nanas.
Mereka kurang mengekspos serat nanas karna memilinnya menjadi tampar besar ataupun menjadikannya komposit yang tertutupi sepenuhnya oleh resin.

Penulis menelaah beberapa penelitian terdahulu mengenai serat nanas diantaranya oleh; [2-5]. [2] meneliti pengaruh material komposit serat nanas dengan matriks HDPE terhadap sifat mekanis dan daya serap air. [3] meneliti peningkatan tekanan serat pada komposit serat nanas melalui pengurangan masa molekul matriks. [4] meniliti pembuatan komposit serat nanas yang than api dan suhu tinggi dengan menambahkan zat tambahan untuk kemudian dijadikan material pembuat komponen otomotif. [5] meneliti serat nanas sebagai material pembuat komponen otomotif. Bayu G. P. dkk meneliti pengaruh penggunaan komposit serat nanas sebagai material pembuat intake manifold sepeda motor.

[2-5] hanya meneliti sifat mekanis dari komposit serat nanas, di lain sisi Bayu G. P. dkk hanya membuat prototype intake manifold sepeda motor untk kemudian dites pengaruhnya terhadap gas buang. Namun komposit serat nanas yang diciptakan oleh Bayu G. P. dkk tidak mengekspos karakter dari serat nanas, serat tertutup penuh oleh resin. Selain itu nilai kekuatan dari komposit serat nanas tidak dimanfaatkan karna hanya dijadikan komponen mesin kendaraan. Dalam kasus ini penulis memfokuskan penelitian pada optimalisasi nilai keindahan karakter dan pemanfaatan nilai kekuatan serat nanas untuk prospek peningkatan bisnis produk berbahan serat nanas.

\section{II.METODOLOGI PENELITIAN}

Metode riset dibagi menjadi 5 yaitu; studi literatur, perlakuan material, eksplorasi bentuk, konsumen dan pasar. Dalam studi perlakuan material terdiri dari 2 tahapan eksperimen. Tahap pertama adalah eksperimen metode cetak dan pewarnaan serat nanas. Eksperimen metode cetak dibagi menjadi 2 tipe eksperimen yang berdasarkan matriks yang digunakan yaitu adhessive dan polyester. Metode pewarnaan dibagi menjai 2 tipe eksperimen berdasarkan jenis pewarnanya yaitu sintetis dan natural.

Temuan dari eksperimen tahap pertama akan menjadi dasar untuk melakukan eksperimen tahap lanjutan. Kesimpulan dari eksperimen tahap lanjutan meliputi analisis luaran produk, proses produksi dan karakteristik komposit serat nanas.

Tahapan selanjutnya adalah studi eksplorasi bentuk dengan menggunakan dasar analisis-analisis di atas. Eksplorasi bentuk dilakukan dengan cara membuat mood-board gaya interior dan referensi bentuk. Studi berikutnya adalah studi konsumen 
dengan membuat persona. Persona merupakan visualisasi dari target konsumen yang mendeskripsikan psikografi dan demografi konsumen di dalamnya.

Studi selanjutnya adalah studi pasar yag dilakukan dengan cara melakukan analisis produk sejenis di pasaran, segmentasi pasar dan positioning.

Hasil dari studi serat analisis di atas merupakan dasar untuk membuat eksplorasi konsep desain. Tahapan akhir dari riset ini adalah mendesain desain akhir lalu membuat rencana bisnis dengan menyusun business model canvas, perhitungan HPP dan BEP, penetapan standarisasi kualitas produk dan proses produksi dimana termasuk di dalamnya terdapat konsep branding and marketing concept.

\section{HASIL DAN PEMBAHASAN}

Hasil dari serangkaian eksperimen dan aalisis menghasilkan proses produksi seperti di bawah ini;

\section{A. Pewarnaan}

Proses pewarnaan diawali dengan merebus 600gr pewarna alam ke dalam 1L air selama 1 jam, angkat kemudian tiriskan pewarna dari air. Kemudian rendam $450 \mathrm{gr}$ serat nanas ke dalam larutan pewarna selama 1 jam. Untuk mendapatkan warna yang gelap perlu untuk merendamnya kembali ke dalam larutan tunjung (5gr tunjung untuk $500 \mathrm{ml}$ air). Dan untk mendapatkan warna yang cerah perlu merendamnya kembali ke dalam larutan tawas (5gr tawas untuk 500ml air).

Pewarna alam yang digunakan meliputi; tejer, jolawe, jambal, tingi, and secang (gambar 5).Berikut merupakan rentang warna yang dihasilkan oleh masing-masing pewarna;

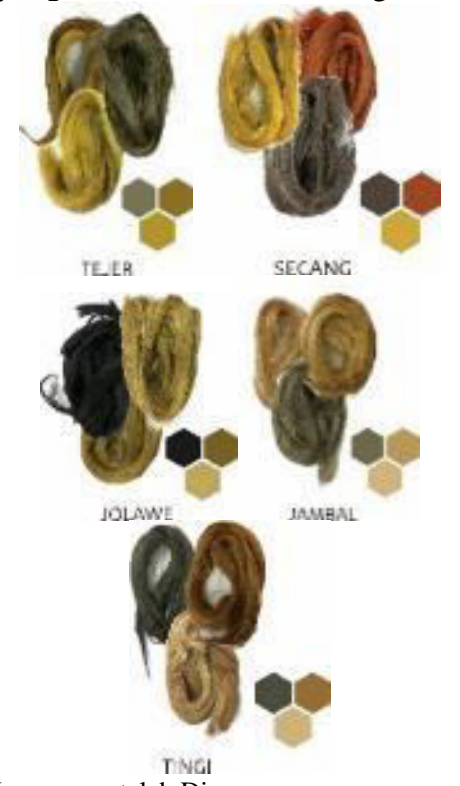

Gambar 1. Serat Nanas yang telah Diwarna.

- Tingi : coklat muda-tua

- Jolawe : hitam-kuning kecoklatan

- Tejer : kuning-hijau tua

- Secang : jingga- ungu

- Jambal : coklat muda - tua

Gelap maupun cerahnya warna yang didapatkan ditentukn oleh pengikat warna (tunjung \& tawas); tunjung untuk menggelapkan warna dan tawas untuk mencerahkan warna.

\section{B. Pemilinan}

Pemilinan serat nanas berwarna menjadi tali dilakukan dengan alat pilin sederhana. Serat nanas dipilin dengn ketebalan $3 \mathrm{~mm}$, karna $3 \mathrm{~mm}$ merupkan ketebalan optimum untuk mengekspos karakteristik serat nanas. Selain tidak terlalu tebal, ketebalan tersebut juga mengespos tekstur dan kekuatan serat. Untuk memproduksi $200 \mathrm{~m}$ tali dibutuhkan $450 \mathrm{gr}$ serat daun nanas.

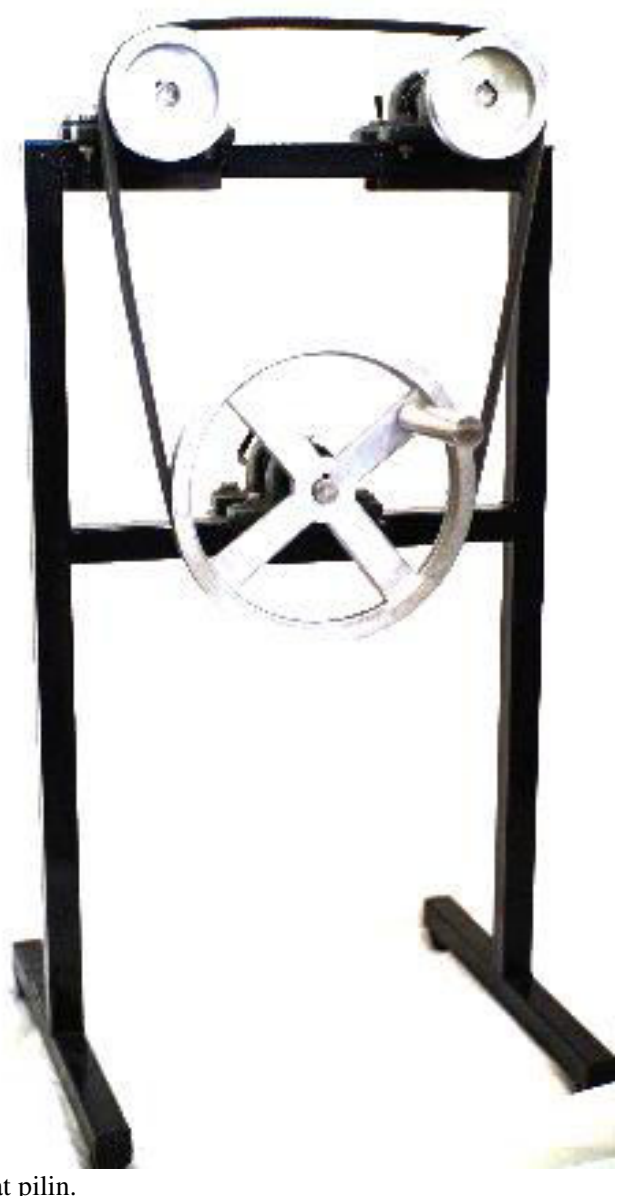

Gambar 2. Alat pilin.

Alat pilin tersebut dibuat berdasarkan hasil survey pengerajin sreat alam di Bantul Yogyakarta. Dibutuhkan alat pilin karna akan mengurangi waktu proses produksi, yang biasanya butuh $2,5 \mathrm{menit} / \mathrm{meter}$ menjadi $1,5 \mathrm{menit} / \mathrm{meter}$. Selain itu sangat sulit untuk menganyam serat tanpa memilinnya menjadi tali

\section{C.Penganyaman}

Penganyaman serat daun nanas dilakukan dengan alat anyam sederhana yang engadaptasi mesin tenun.

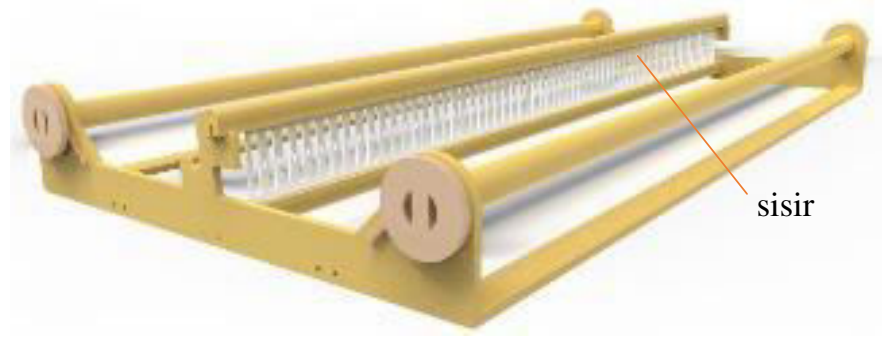

Gambar 3. Alat Anyam. 
Dalam riset ini kami mengembangkan pattern yang ditentukan berdasarkan pola sisir pada alat anyamnya.

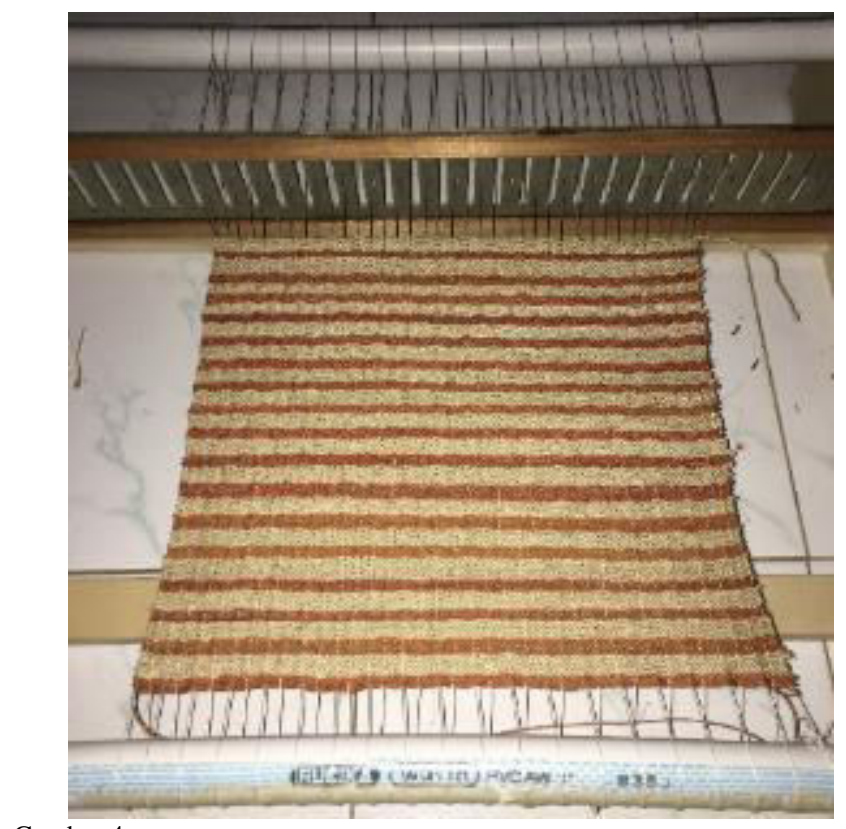

Gambar 4. proses penganyaman.

Berikut ini merupakan pattern lembaran beserta pola sisir pembentuknya.

a. Pola pertama merupakan kombinasi 3,7 dimana pola tersebut mengkombinasikan perbedaan jumlah pilinan serat nanas.

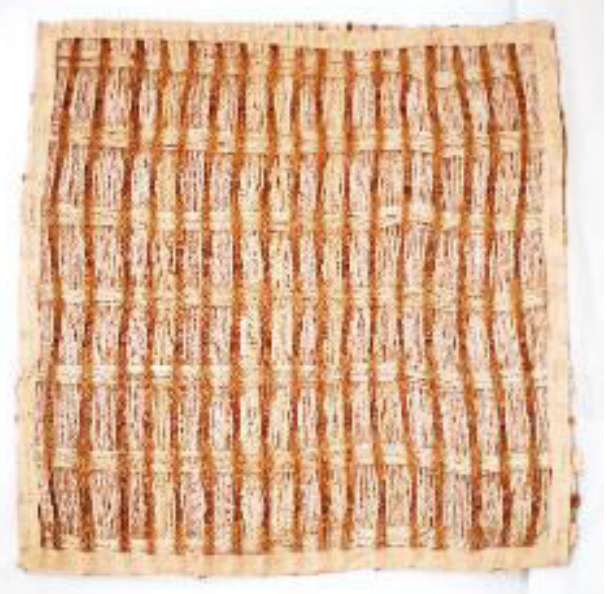

Gambar 5. pattern 1.

Jumlah baris sisir tenun adalah 1 dengan pola sisir sebagai berikut;

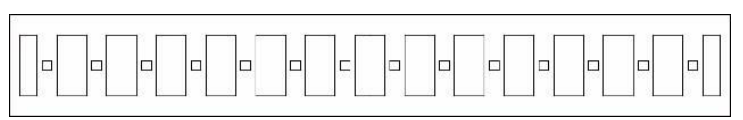

Gambar 6 Pattern sisir 1.

b. Pola kedua merupakan pola konvensional yaitu kombinasi 1,1. Pola bergaris diperoleh dari penganyaman warna yang berbeda secara bergantian

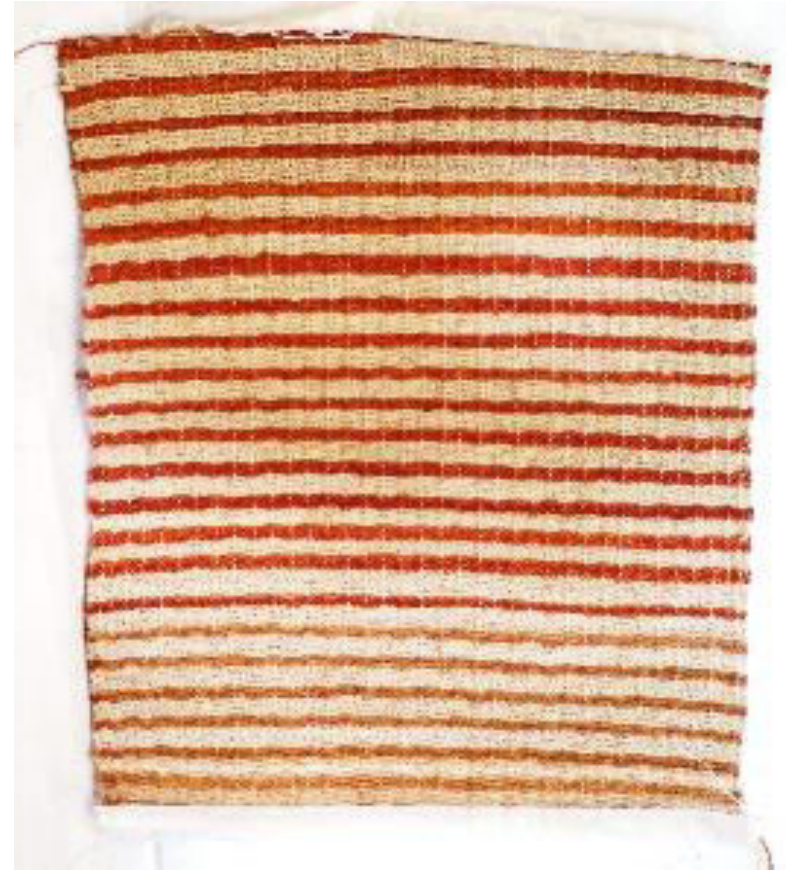

Gambar 7. pattern 2.

Berikut ini merupakan pola sisir pembentuk pattern di atas;

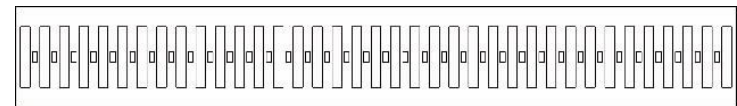

Gambar 8. pattern sisir 2.

c. Pola terpilih merupakan kombinasi 3 warna yang membentuk pola bergaris vertical.

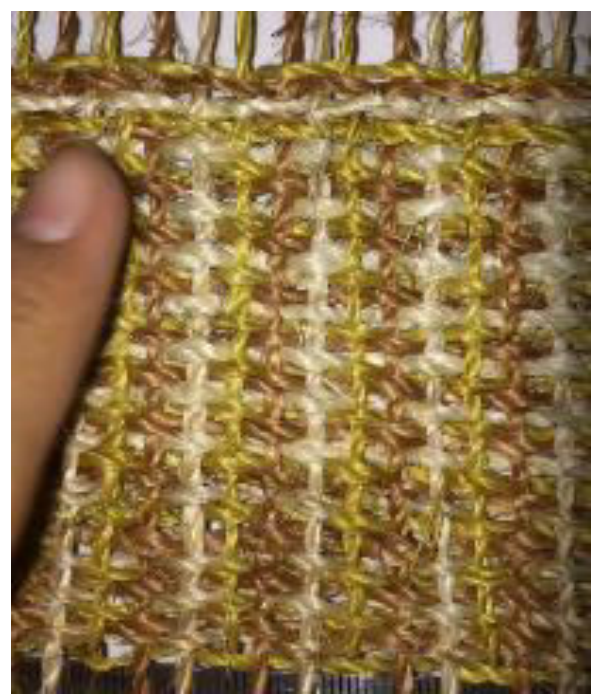

Gambar 9. pattern 3.

Pattern ini membutuhkan 3 baris sisir yang berbeda dan disuruk berurutan dari depan- ke belakang.

1. Baris pertama

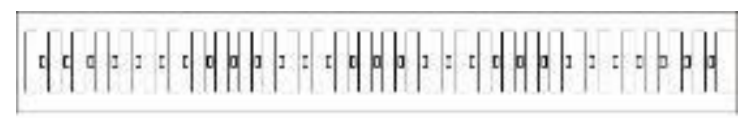

Gambar 10. baris pertama. 
2. Baris kedua

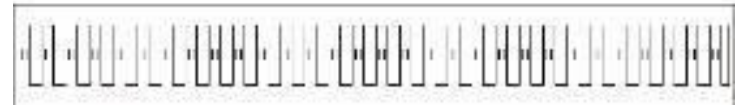

Gambar 11. baris kedua.

3. Baris ketiga

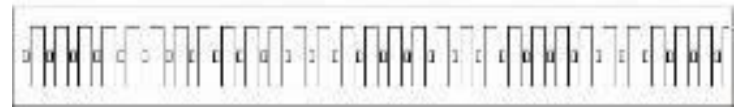

Gambar 12. baris ketiga.

Penggunaan alat penganyaman sederhana meningkatkan efisiensi waktu penganyaman dan proses produksi. Pola motif dari lembaran yang dihasilkan ditentukan oleh pola sisir alat anyamnya.

\section{Proses Cetak Komposit}

Proses cetak komposit enggunakan metode vacuum bag molding dimana membutuhkan;

a. Resin Polyester (Yucalac BQTN 157)

b. Katalis MEKPO

c. Plastic tipis berpori $1 \mathrm{mx} 1 \mathrm{~m}$

d. Plastik tebal $1 \mathrm{mx} 1 \mathrm{~m}$

e. Cetakan yang telah di-cnc

f. PVA

g. Mesin vakum

h. Kain flanel

Proses cetak komposit dengan metode vacuum bag molding meliputi;

1. Letakkan lembarat serat nanas pada cetakan yang sebelumnya telah diolesi PVA

2. Buat adonan resin dengan pebandingan resin dan katalia 1:3 (perbandingan serat dan adonan resin adalah 60:40)

3. Tuang resin pada serat sambil ditekan agar menyerap sempurna

4. Letakkan platik tipis berpori di atas serat yang telah dituang resin, kemudian letakkan kain flanel dan yang terakhir segel dengan plastik tebal dimana sebelumnya telah dimasukkan selang vakum. Pastikan tidak ada lubang udara agar tidak bocor.

5. Vakum selama 1 jam dengan 3 kali pengulangan, diamkan selama 5 jam hingga resin mengeras sempurna.

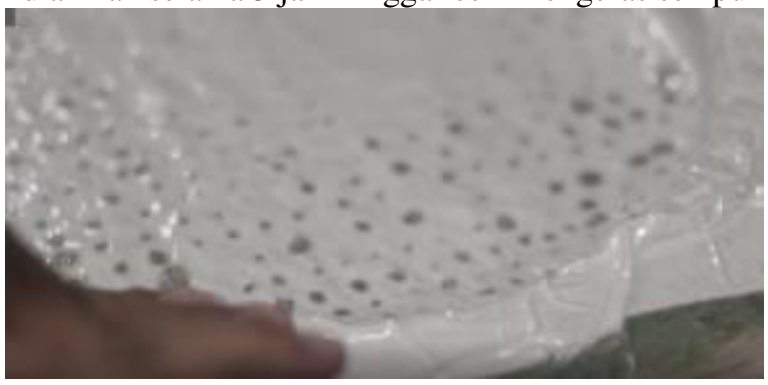

Gambar 13. proses cetak komposit serat nanas.

Komposit serat nanas yang dihasilkan kaku, presisi mengikuti bentuk cetakan dan terlihat pola anyaman seratnya. Pengesposan tekstur bergantung pada cetakan yang digunakan (positif atau negatif) dan produk yang akan dihasilkan.

Salah satu produk yang dapat dihasilkan dari komposit serat nanas adalah stool dapat dilihat pada Gambar 19.

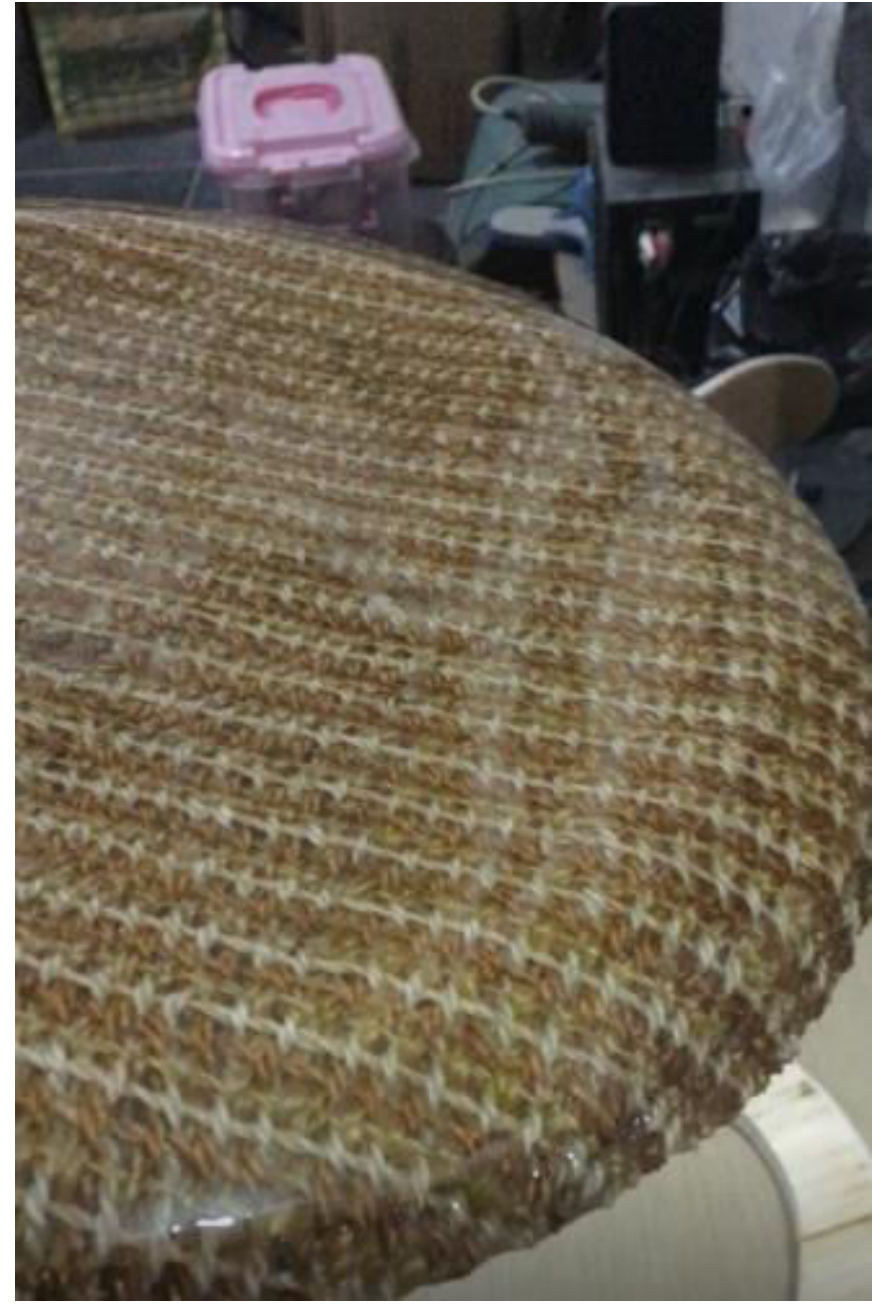

Gambar 14. hasil komposit serat nanas.

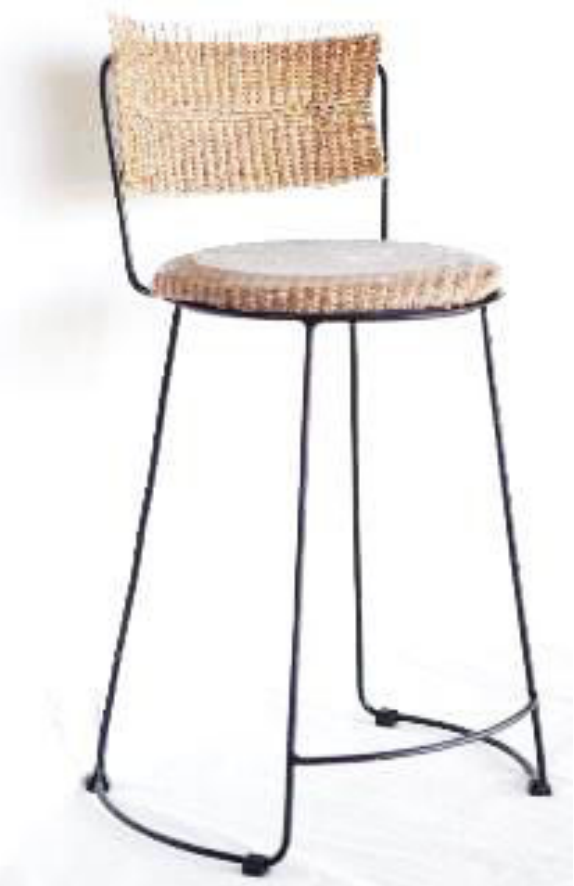

Gambar 19. Prototype stool. 
Lembaran anyaman serat nanas akan lebih efisien apabila dicetak menjadi komposit dengan metode vacuum bag molding. Karena bentuk yang dihasilan akan presisi sesuai dengan cetakannya dan resin yang meresap pada serat juga tidak berlebihan. Ekspose tekstur serat ditentukan oleh jenis cetakan (positif/negatif) yang digunakan. Cetakan positif akan menghasilkan permukaan bertekstur sedangkan cetakan negatif akan menghasilkan permukaan yang rata tertutup resin.

\section{KESIMPULAN DAN SARAN}

\section{A. Kesimpulan}

1. Nilai Kekuatan serat nanas dapat dioptimalisasi melalui kombinasi dengan material lain, salah satunya dijadikan komposit dengan matriks resin polyester dan katalis MEKPO. Metode yang digunakan adalah vacuum bag molding, karena bentuk produk akan presisi sesuai molding. Dengan sebelumnya melalui tahap pembuatan lembaran serat nanas sebagai berikut;

a. Dijadikan lembaran anyaman dengan metode;

- Manual : cara manual didapat dengan menganyam serat nanas tanpa menggunakan alat anyam dan media penunjangnya meliputi rangka dan jarum

- Alat anyam : alat anyam merupakan adaptasi dari alat tenun sederhana, terdapat dudukan dan sisir. Dimana pattern sisir akan menentukan pola/ motif yang akan dihasilkan

b. Menjadikannya anyaman lembaran dengan komposisi: Untuk lembaran serat berukuran $55 \times 45 \mathrm{~cm}^{2}$ dan tebal $3 \mathrm{~mm}$ membutuhkan serat sepanjang 200 meter dan seberat $450 \mathrm{gr}$.

2. Nilai estetika serat nanas dapat dioptimalisasi melalui;

a. Memilinnya dengan alat anyam dengan ketebalan $3 \mathrm{~mm}$, karena $3 \mathrm{~mm}$ merupakan diamter serta ketebalan optimum untuk mengekspos karakter serat nanas yang kuat dan mengkilap.

b. Serat nanas dapat diwarna dengan direndam ke dalam pewarna alam dengan komposisi, untuk $150 \mathrm{gr}$ serat nanas membutuhkan pewarna sebanyak 600gr kayu pewarna dan air sebanyak 1 Liter. Serat yang telah direndam pewarna direndam ke dalam $5 \mathrm{gr}$ tunjung dan $500 \mathrm{ml}$ air untuk mendapatkan warna gelap dan $5 \mathrm{gr}$ tawas dan $500 \mathrm{ml}$ air untuk mendapatkan warna yang cerah.

- Serat dapat dianyam langsung pada rangka maupun dibuat lembaran terlebih dahulu. Bentuk rangka yang dapat dianyam meliputi; lingkaran, persegi dan bentuk lainnya.

3. Nilai ekonomi serat nanas dapat dioptimalisasi melalui peningkatan nilai yang meliputi;

- Dijadikan produk furnitur

- Dianyam menggunakan alat anyam sederhana

- Dianyam membentuk pola khas DNA serat nanas

\section{B. Saran}

a. Serat nanas masih dapat dikembangkan menjadi produk lain selain furnitur dengan material lembaran diantaranya adalah; home decor, bike fender dengan metode cetak salah satunya adalah vacuum bag molding b. Produk berbahan serat nanas harus melalui tahap kontrol kualitas dan standarisasi produk, bukan hanya kualitas dari komposit serat nanas namun juga soal finishing dan detail produk.

c. Serat nanas masih dapat dikembangkan dengan kombinasi dengan material lain seperti; rotan, kayu, bambu

d. Serat nanas masih dapat dieksplorasi lebih jauh pengembangannya mengenai desain sistem sambungan antara serat nanas dengan material lain.

e. Serat nanas masih dapat dieksplorasi pengembangannya mengenai pembuatan anyaman dengan pola asimetris

\section{DAFTAR PUSTAKA}

[1] Kirby, Vegetables Fibre. London: Leonard Hill, 1963.

[2] M. Singh Bahra, V. K. Gupta, and L. Anggarwal, "Effect of fibre Content on Mechanical Properties and Water Absorbtion Behaviour of Pineappla/HDPE Composite," in Material Today: Proceedings 4, 2017, pp. 3207-3214.

[3] T. Yantaboot, Kanokwan, Amornsakchai, "Effect of Macctication time on The Low Strain Properties on short Pineapple Leaf Fiber Reinforced Natural Rubber composite," Polim. Test., vol. 57, pp. 31-37, 2017.

[4] R. Erningsih, T. Mutia, and H. Judawisastra, "Komposit Sunvisor Tahan Api dari Bahan Baku Serat Nanas," J. Ind., vol. 5, no. 2, pp. 191-203, 2011.

[5] T. Rihayat and S. Suryani, "Pembuatan Polimer Komposit Ramah Lingkungan untuk Aplikasi Industri Otomotif dan elektronik," in SNaPP: Sains dan Teknologi, 2012. 